\title{
Inhibitory Effects of Fungal Bis(naphtho- $\gamma$-pyrone) Derivatives on Nitric Oxide Production by a Murine Macrophage-Like Cell Line, RAW 264.7, Activated by Lipopolysaccharide and Interferon- $\boldsymbol{\gamma}^{1)}$
}

\author{
Rie IshiI, ${ }^{a}$ Masakazu Horie, ${ }^{a}$ Kiyotaka KoYama, ${ }^{b}$ Yukihiro IshiKawa, ${ }^{c}$ and Susumu KitanaKA ${ }^{*}, d$ \\ ${ }^{a}$ Saitama Institute of Public Health; 639-1 Kamiokubo, Sakura-ku, Saitama, Saitama 338-0824, Japan: ${ }^{b}$ Department of \\ Pharmacognosy and Phytochemistry, Meiji Pharmaceutical University; 2-522-1 Noshio, Kiyose, Tokyo 204-8588, Japan: \\ ${ }^{c}$ Faculty of Regional Sciences, Tottori University; 4-101 Koyama-Minami, Tottori 680-8551, Japan: and ${ }^{d}$ College of \\ Pharmacy, Nihon University; 7-7-1 Narashinodai, Funabashi, Chiba 274-8555, Japan. \\ Received October 8, 2004; accepted February 8, 2005
}

Inhibitory effects of six fungal bis(naphtho- $\gamma$-pyrone) derivatives on nitric oxide (NO) production by a murine macrophage-like cell line, RAW 264.7, which was activated by lipopolysaccharide and interferon- $\gamma$ were examined. Among these derivatives, chaetochromin (4) (IC $50.8 \mu \mathrm{M})$, cephalochromin (1) (IC $\left.\mathrm{IC}_{50} 1.5 \mu \mathrm{M}\right)$, and dihydroisoustilaginoidin A (6) (IC $\left.\mathrm{IC}_{50} 2.8 \mu \mathrm{M}\right)$ exhibited strong inhibitory activity. The bis(naphtho- $\gamma$-pyrone) derivatives did not affect the enzyme activity of inducible nitric oxide synthase (iNOS). However, these derivatives significantly reduced both the induction of iNOS protein and iNOS mRNA expression. These results suggest that the bis(naphtho- $\gamma$-pyrone) derivatives have the pharmacologic ability to suppress NO production by activated macrophages.

Key words naphtho- $\gamma$-pyrone; macrophage; nitric oxide; cephalochromin; chaetochromin

Macrophages play an important role in nonspecific host defense mechanisms. ${ }^{2)}$ Among a variety of mediators released by activated macrophages, ${ }^{3)}$ nitric oxide (NO) has been identified as a potent molecule that may exert regulatory or cytotoxic effects on tumor cells and microbes. ${ }^{4-6)}$ The enzyme responsible for the synthesis of NO in macrophages is inducible nitric oxide synthase (iNOS), which does not occur ordinarily but is strongly induced upon exposure to bacterial endotoxin and inflammatory cytokines. ${ }^{7,8)}$ The excessive production of NO during inflammation may also lead to severe injury to host cells and tissues. ${ }^{9)}$ This suggests that inhibition of chronic NO production in macrophages could be a target for potential antiinflammatory drugs.

In the course of our screening program to obtain a novel iNOS inhibitor, we found that some fungal bis (naphtho- $\gamma$ pyrone) derivatives, such as cephalochromin (1), chaetochromin A (4), and dihydroisoustilaginoidin A (6) inhibited NO production by activated macrophages that had been treated with lipopolysaccharide (LPS) and interferon (IFN)$\gamma$. These compounds are reported to exhibit antibacterial activity $^{10)}$ and antitumor activity. ${ }^{11-13)}$ However, the physiologic and pathologic functions of these compounds have not been fully clarified. The present paper describes the inhibition of NO production and the mechanisms by which these fungal bis(naphtho- $\gamma$-pyrone) and related compounds act.

\section{MATERIALS AND METHODS}

Materials Cephalochromin (1), chaetochromin A (4), and dihydroisoustilaginoidin A (6) were metabolites of Cephalosporium sp., Chaetomium sp., and Acremonium butyri, respectively. Cephalosporium sp. was extracted with acetone, suspended in water, and extracted with chloroform. Compound 1 was obtained by separation of the chloroform fraction by column chromatography on silica gel and by purification with HPLC. Compound 4, chaetochromin A 5,5'- dimethyl ether (5), and $\mathbf{6}$ were obtained as described in previous papers. ${ }^{12,14)}$ Cephalochromin 5-methyl ether (2), and cephalochromin 5,5'-dimethyl ether (3) were obtained from 1 by methylation with ethereal $\mathrm{CH}_{2} \mathrm{~N}_{2}$ in a water bath for $4 \mathrm{~h}$ and by separation on HPLC. The structural formulae of these compounds are shown in Fig. 1. Ham's F12 medium was obtained from Sigma (St. Louis, MO, U.S.A.), and fetal bovine serum from GIBCO BRL (Grand Island, NY, U.S.A.), IFN- $\gamma$ from Genzyme (Cambridge, MA, U.S.A.), LPS (Escherichia coli O55:B5) from Difco (Detroit, MI, U.S.A.), and 2-(4-carboxyphenyl)-4,4,5,5-tetramethyl-imidazoline-3-oxide-1-oxyl (carboxy-PTIO) from Dojindo Laboratories (Kumamoto, Japan). ${ }^{125} \mathrm{I}$-Labeled protein A was purchased from Amersham Pharmacia Biotech UK Ltd. (Amersham, U.K.). All other chemicals and reagents were of the purest commercial grade available.

Cell Culture RAW 264.7 cells, a mouse macrophagelike cell line transformed with the Abelson leukemia virus, were obtained from the American Type Culture Collection (Rockville, MD, U.S.A.). The cells were maintained by culturing in Ham's F12 medium supplemented with 10\% heatinactivated fetal bovine serum in a $\mathrm{CO}_{2}$ incubator $\left(5 \% \mathrm{CO}_{2}-\right.$ $95 \%$ humidified air) at $37^{\circ} \mathrm{C}$. The cells were seeded onto plastic Petri dishes (Falcon, \#1001; Becton Dickinson) and passaged twice a week.

Cell Viability Cell viability was determined using the MTT method and through morphologic observations. RAW 264.7 cells $\left(1.0 \times 10^{4}\right.$ cells/well $)$ in 96 -well plates were exposed to various concentrations of compounds with LPS $100 \mathrm{ng} / \mathrm{ml}$ and IFN- $\gamma 10 \mathrm{U} / \mathrm{ml}$ at $37^{\circ} \mathrm{C}$ for $16 \mathrm{~h}$. 3-(4,5-Dimethyl thiazol-2yl)-2,5-diphenyl tetrasodium (MTT) $10 \mu \mathrm{l}$ solution $(5 \mathrm{mg} / \mathrm{ml})$ was added, and further incubation followed for $4 \mathrm{~h}$ at $37^{\circ} \mathrm{C}$. After aspirating the supernatant from the wells, $100 \mu \mathrm{l}$ of dimethylsulfoxide was added to dissolve formazan crystals. The absorbance of each well was then read at $550 \mathrm{~nm}$ using an MTP-120 microplate reader (Corona Electric Co., Ltd., Japan). 


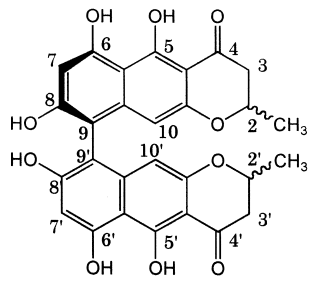

1

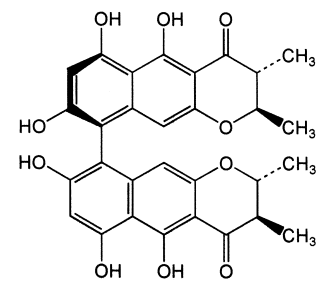

4

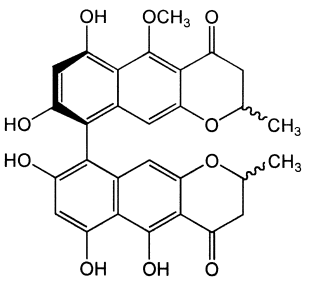

2

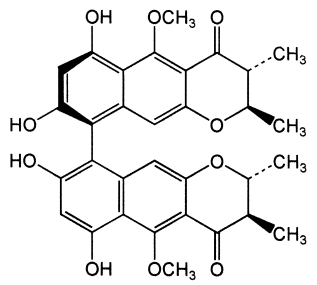

5

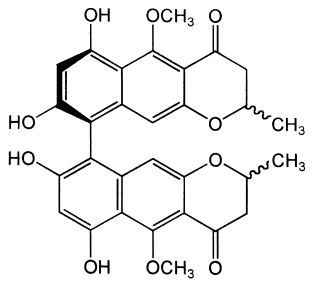

3

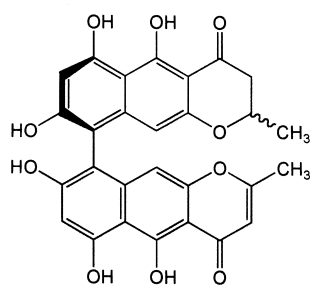

6

Fig. 1. Chemical Structures of the Bis(naphtho- $\gamma$-pyrone) Derivatives Examined in the Present Study

NO Production Assay and iNOS Induction in Macrophages The cells were plated at $1.2 \times 10^{6}$ cells $/ \mathrm{ml}$ onto a 35-mm Petri dish (Sumitomo Bakelite, \#1135R; Tokyo, Japan), and then incubated at $37^{\circ} \mathrm{C}$ for $2 \mathrm{~h}$. A test compound and both LPS $100 \mathrm{ng} / \mathrm{ml}$ and IFN- $\gamma 10 \mathrm{U} / \mathrm{ml}$ were added to the culture medium, and the cells were incubated at $37^{\circ} \mathrm{C}$ for $16 \mathrm{~h}$. After incubation, the cells were chilled on ice, scraped from the dish using a cell scraper, collected in a microfuge tube, and then centrifuged at $2800 \times \mathbf{g}$ for $1 \mathrm{~min}$. The supernatant was placed in a new microfuge tube for analysis of nitrite $\left(\mathrm{NO}_{2}^{-}\right)$-oxidized NO. The cells were washed twice with phosphate-buffered saline (PBS) without divalent cations by repeated centrifugation at $2800 \times \mathbf{g}$. The final cell pellet was extracted with $35 \mu \mathrm{l}$ of a lysis buffer comprised of $1 \%(\mathrm{v} / \mathrm{v})$ Triton X-100, EDTA $0.1 \mathrm{~mm}$, and $1 \%$ aprotinin (Sigma Chemical) in HEPES-NaOH buffer $20 \mathrm{~mm}(\mathrm{pH} 7.5)$ at $4{ }^{\circ} \mathrm{C}$ for $30 \mathrm{~min}$. The cell lysate was centrifuged at $5500 \times$ g at $4{ }^{\circ} \mathrm{C}$ for $1 \mathrm{~min}$. A $30-\mu \mathrm{l}$ aliquot of the resultant supernatant was placed in a new microfuge tube. The final cell extract was used for Western blot analysis.

iNOS Activity in Intact Macrophages Preactivated with LPS and IFN- $\gamma$ The inhibitory effects of the compounds on iNOS activity in intact cells were examined using a previously reported method. ${ }^{15)}$ In brief, macrophages were treated with LPS $100 \mathrm{ng} / \mathrm{ml}$ and IFN- $\gamma 10 \mathrm{U} / \mathrm{ml}$ at $37^{\circ} \mathrm{C}$ for $16 \mathrm{~h}$, the cells were collected, washed three times with PBS, and suspended at $4 \times 10^{5}$ cells $/ \mathrm{ml}$ in modified Hank's balanced salt solution. A $500 \mu \mathrm{l}$ volume of cells was reseeded onto a 24well plate (Sumitomo Bakelite, \#8024R). After incubation for $10 \mathrm{~min}$, one of the compounds was added, followed by incubation at $37^{\circ} \mathrm{C}$ for $5 \mathrm{~min}$, and then by the addition of carboxy-PTIO $100 \mu \mathrm{M}$ and L-arginine $1 \mathrm{~mm}$ to start the reaction. The cells were incubated for $0-60 \mathrm{~min}$, and the amount of $\mathrm{NO}_{2}^{-}$in the culture supernatant was determined. This detection method for $\cdot \mathrm{NO}$ was used for a macrophage culture with carboxy-PTIO, a scavenger of - NO. Carboxy-PTIO rapidly converts $\cdot \mathrm{NO}$ to $\cdot \mathrm{NO}_{2}$, and then to $\mathrm{NO}_{2}^{-}$, and enabled us to determine iNOS activity in intact macrophages in a short incubation period.

Western Blot Analysis of iNOS Protein Western blot analysis was performed according to the reported method. ${ }^{16)}$ Protein cell extract $60 \mu \mathrm{g}$ obtained as described above was boiled in an SDS-sample buffer, loaded onto a 5-20\% gradient slab gel (Atto, Tokyo, Japan), and electrophoresed at $20 \mathrm{~mA} / \mathrm{gel}$. The proteins in the gel were electrotransferred onto a polyvinylidene fluoride membrane (Immobilon-P, Millipore, Bedford, MA, U.S.A.). The proteins on the membrane were probed with a monoclonal anti-macrophage iNOS antibody (Transduction Laboratories, Lexington, KY, U.S.A.), then with rabbit anti-mouse IgG (Zymed Laboratories, Inc., San Francisco, CA, U.S.A.), and finally with ${ }^{125}$ I-labeled protein A. After air-drying, the membrane was placed on an Xray film, and the bands on the membrane were photographed. The radioactivity of the bands corresponding to iNOS was quantitated on an auto well $\gamma$-counter (ARC-300; Aloka Co., Ltd.)

Reverse Transcription-Polymerase Chain Reaction Analysis of iNOS mRNA The cells were cultured at $1.2 \times$ $10^{6}$ cells $/ \mathrm{ml}$ at $37^{\circ} \mathrm{C}$ for $2 \mathrm{~h}$, and then one of the compounds was added to the culture medium together with LPS $100 \mathrm{ng} / \mathrm{ml}$ and IFN- $\gamma 10 \mathrm{U} / \mathrm{ml}$, and the cells were incubated for $6 \mathrm{~h}$. Total RNA was isolated from the cell pellets using an RNA isolation kit (QIAGEN, Hilden, Germany). The final amount of RNA was determined by absorbance at $260 \mathrm{~nm}$. Fifty nanograms of the RNA samples were reverse-transcribed into cDNA in RT-PCR using the oligo $(\mathrm{dT})_{12-18}$ primer. The PCR samples contained $25 \mu$ of the reaction mixture, comprised of $\mathrm{KCl} 50 \mathrm{~mm}, \mathrm{MgCl}_{2} 5 \mathrm{~mm}$, dNTP $0.16 \mathrm{~mm}, 5.0$ units of Taq DNA polymerase (Takara Shuzo, Shiga, Japan), and 5 pmol of sense and antisense primers in Tris-HCl $10 \mathrm{~mm}$ (pH 8.3). The sense primer for iNOS was 5'-ACCTACTTCCTGGACATTACGACC C-3', and the antisense primer was $5^{\prime}$-AAGGGAGCAATGCCCGTACCAGGCC-3'. The sense primer for $\beta$-actin was $5^{\prime}$-GTGGGCCGCTCTAGGCACCAA- $3^{\prime}$, and the antisense primer was $5^{\prime}$ CTCTTTGATGTCACGCACGATTTC- $3^{\prime} .{ }^{17)}$ The PCR reaction was performed under the following conditions: 25 cycles of denaturation at $94^{\circ} \mathrm{C}$ for $1 \mathrm{~min}$, annealing at $57^{\circ} \mathrm{C}$ for $1 \mathrm{~min}$, and extension at $72^{\circ} \mathrm{C}$ for $1.5 \mathrm{~min}$, using a thermal cycler (GeneAmp ${ }^{\circledR}$ PCR Systems 9700; PE Applied Biosys- 
tems, U.S.A.). The PCR products were run on a $2 \%$ agarose gel and visualized by ethidium bromide staining. The bands in the gel were photographed and their fluorescence intensity was analyzed using a densitometer (CS-930; Shimadzu Scientific Instrument and Equipment, Kyoto, Japan).

Nitrite Assay Duplicate 100- $\mu$ l aliquots of the culture supernatant were placed in the well of a 96-well flat-bottomed plate. A standard solution of $\mathrm{NaNO}_{2}$ was also placed in other wells on the same plate. To quantitate $\mathrm{NO}_{2}^{-}, 50 \mu \mathrm{l}$ of Griess reagent, $1 \%$ sulfanilamide in $5 \% \mathrm{H}_{3} \mathrm{PO}_{4}$, and $0.1 \% \mathrm{~N}$ 1-naphthylethylenediamine dihydrochloride were added to each well. ${ }^{18)}$ After $10 \mathrm{~min}$, the reaction products were colorimetrically quantitated at $550 \mathrm{~nm}$ after subtraction of the background absorbance at $630 \mathrm{~nm}$, using a microplate reader.

Protein Assay Protein concentrations were determined according to the method of Bradford, using bovine serum albumin as the standard. ${ }^{19)}$

Statistical Analysis Results were analyzed for statistical significance using Dunnett's test for multiple comparisons.

\section{RESULTS AND DISCUSSION}

Cell Viability To confirm that the inhibitory effect of bis(naphtho- $\gamma$-pyrone) derivatives on NO production was not due to cytotoxicity, we examined their effects on cell viabil- ity. As shown in Table 1, $1(10 \mu \mathrm{M}), 4(10 \mu \mathrm{M})$, and $6(10 \mu \mathrm{M})$ showed some effects on cell viability as compared with LPS + IFN- $\gamma$-treated control cells. Therefore concentrations of compounds 1, 4, and $\mathbf{6}$ were set at less than $3 \mu \mathrm{M}$. All experiments were performed under conditions that did not affect cell viability.

Inhibitory Effects on NO Production by Activated Macrophages When the cells were incubated with LPS $100 \mathrm{ng} / \mathrm{ml}$ and IFN- $\gamma 10 \mathrm{U} / \mathrm{ml}$ for $16 \mathrm{~h}$, NO production increased markedly (Fig. 2). However, the control cells without any addition showed no production (data not shown). Among six bis(naphtho- $\gamma$-pyrone) derivatives, compounds $\mathbf{1}\left(\mathrm{IC}_{50}\right.$ $1.5 \mu \mathrm{M}), 4\left(\mathrm{IC}_{50} 0.8 \mu \mathrm{M}\right)$, and $6\left(\mathrm{IC}_{50} 2.8 \mu \mathrm{M}\right)$ exhibited strong inhibitory activities. To examine relationship between inhibitory activity and the presence of phenolic hydroxyl groups at the C-5 or C-5' positions in the bis(naphtho- $\gamma$-pyrone) ring, we synthesized $\mathbf{2}$ and $\mathbf{3}$ from $\mathbf{1}$, and $\mathbf{5}$ from $\mathbf{4}$. Compound 1 exhibited strong inhibition, whereas $\mathbf{2}$ showed little inhibition, and $\mathbf{3}$ did not inhibit NO production even at $10 \mu \mathrm{M}$. Similarly, inhibition by 5 was weaker than that by 4 . Methylation of the phenolic hydroxyl groups at the C-5 and $\mathrm{C}-5^{\prime}$ positions in bis(naphtho- $\gamma$-pyrone) ring decreased these inhibitory activities. The presence of the phenolic hydroxyl groups in bis(naphtho- $\gamma$-pyrone) rings was necessary for the inhibition. Koyama et al. reported that bis(naphtho- $\gamma$-pyrone)

Table 1. Cell Viability of RAW 264.7 Cells Incubated with the Bis(naphtho- $\gamma$-pyrone) Derivatives in the Presence of LPS $100 \mathrm{ng} / \mathrm{ml}$ and IFN- $\gamma 10 \mathrm{U} / \mathrm{ml}$

\begin{tabular}{|c|c|c|c|c|c|}
\hline & Reagent conc. $(\mu \mathrm{M})$ & Cell viability (\%) & & Reagent conc. $(\mu \mathrm{M})$ & Cell viability (\%) \\
\hline Control & & $100.0 \pm 2.1$ & & & \\
\hline \multirow[t]{4}{*}{1} & 0.3 & $99.5 \pm 6.4$ & 4 & 0.3 & $107.3 \pm 8.9$ \\
\hline & 1 & $101.4 \pm 2.8$ & & 1 & $103.3 \pm 2.3$ \\
\hline & 3 & $103.6 \pm 3.2$ & & 3 & $94.3 \pm 6.9$ \\
\hline & 10 & $70.5 \pm 4.5^{* *}$ & & 10 & $64.2 \pm 3.5^{* *}$ \\
\hline \multirow[t]{4}{*}{2} & 0.3 & $107.3 \pm 6.5$ & 5 & 0.3 & $104.2 \pm 5.1$ \\
\hline & 1 & $100.3 \pm 5.3$ & & 1 & $97.7 \pm 5.6$ \\
\hline & 3 & $99.4 \pm 4.0$ & & 3 & $106.4 \pm 1.5^{*}$ \\
\hline & 10 & $104.2 \pm 6.3$ & & 10 & $96.1 \pm 4.8$ \\
\hline \multirow[t]{4}{*}{3} & 0.3 & $105.4 \pm 2.0^{*}$ & 6 & 0.3 & $98.9 \pm 5.8$ \\
\hline & 1 & $94.1 \pm 3.2$ & & 1 & $99.9 \pm 3.2$ \\
\hline & 3 & $107.4 \pm 5.7$ & & 3 & $102.5 \pm 4.9$ \\
\hline & 10 & $96.1 \pm 5.3$ & & 10 & $78.6 \pm 5.6^{* *}$ \\
\hline
\end{tabular}

Cells were incubated with various concentrations of compounds in the presence of LPS $100 \mathrm{ng} / \mathrm{ml}$ and IFN- $\gamma 10 \mathrm{U} / \mathrm{ml}$ for $16 \mathrm{~h}$. The viable cell number was determined using the MTT method. The results were expressed as the mean \pm S.E. of two independent experiments involving triplicate assays. $* p<0.05, * * p<0.01, v s$. the corresponding controls (cells treated with LPS $100 \mathrm{ng} / \mathrm{ml}$ and IFN- $\gamma 10 \mathrm{U} / \mathrm{ml}$ ).
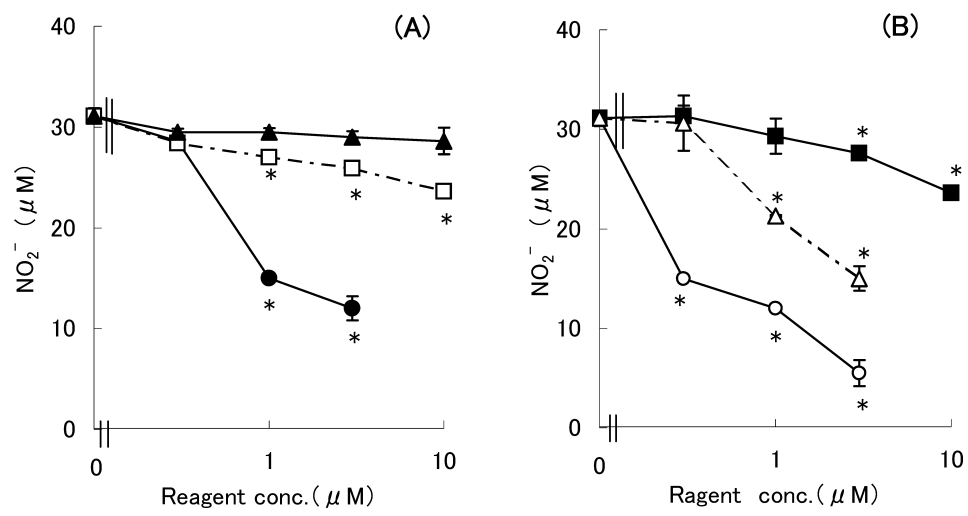

Fig. 2. Inhibitory Effects of the Bis(naphtho- $\gamma$-pyrone) Derivatives on NO Production

Cells were treated with various concentrations of compounds 1,2 , and $\mathbf{3}$ (A), compounds $4, \mathbf{5}$, and $\mathbf{6}$ (B) in the presence of LPS $100 \mathrm{ng} / \mathrm{ml}+\mathrm{IFN}-\gamma 10 \mathrm{U} / \mathrm{ml}$ at $37{ }^{\circ} \mathrm{C}$ for $16 \mathrm{~h}$. The symbols correspond to: (A) 1 (-O-), 2 (- $\square-$ ), and $\mathbf{3}(-\mathbf{\Delta}-)$, and (B) 4 (-O-), 5 (-口-), and $\mathbf{6}(-\triangle-)$. The results are the means \pm S.E. of two independent experiments comprising duplicate assays. $* p<0.01 v s$. the corresponding controls (cells treated with LPS $100 \mathrm{ng} / \mathrm{ml}+\mathrm{IFN}-\gamma 10 \mathrm{U} / \mathrm{ml})$. 
derivatives such as $\mathbf{1}$ and $\mathbf{4}$ exhibit strong antitumor activity, and methylation of the phenolic hydroxyl groups at the C-5 and $\mathrm{C}-5^{\prime}$ positions in the bis(naphtho- $\gamma$-pyrone) ring decrease antitumor activity. ${ }^{11)}$ Our results were similar to theirs. Compound 4 exhibited slightly more potent inhibition than $\mathbf{1}$. Compound $\mathbf{5}$ similarly exhibited stronger inhibitory activity than 3. These results indicate that the presence of methyl groups at the C-3 and C-3' position in the bis(naphtho- $\gamma$-pyrone) rings leads to stronger inhibition than in their absence. Time-course experiments showed that the release of $\mathrm{NO}_{2}^{-}$ was first observed $6 \mathrm{~h}$ after incubation with LPS $100 \mathrm{ng} / \mathrm{ml}$ and IFN- $\gamma 10 \mathrm{U} / \mathrm{ml}$ (Fig. 3). The amount of $\mathrm{NO}_{2}^{-}$subsequently increased essentially linearly with time up to $16 \mathrm{~h}$. Compounds $1(3 \mu \mathrm{M}), 4(3 \mu \mathrm{M})$, and $6(3 \mu \mathrm{M})$ exhibited continuous inhibition of NO production for up to $16 \mathrm{~h}$.

Inhibitory Effects on iNOS Activity We attempted to determine whether the inhibitory effects of bis(naphtho- $\gamma$ pyrone) derivatives on NO production were direct effects on the intrinsic enzyme activity of iNOS, or whether these effects were mediated by some other mechanism. CarboxyPTIO converts $\cdot \mathrm{NO}$ to $\cdot \mathrm{NO}_{2}$, and then to $\mathrm{NO}_{2}^{-}$in a fully stoichiometric manner. ${ }^{20)}$ As shown in Fig. 4, LPS and IFN- $\gamma$ treated cells produced $4.3 \mathrm{nmol} \mathrm{NO}_{2}^{-} / 60 \mathrm{~min} / 2.0 \times 10^{5}$ cells

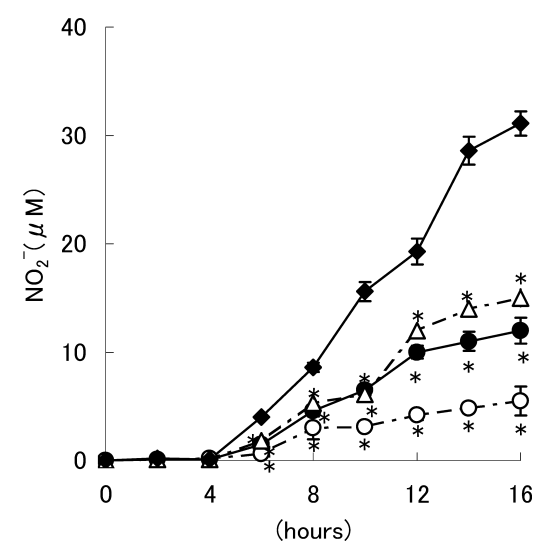

Fig. 3. Time Course of Inhibition of NO Production by the Bis(naphtho- $\gamma$ pyrone) Derivatives

Cells were treated with the bis(naphtho- $\gamma$-pyrone) derivatives in the presence of LPS $100 \mathrm{ng} / \mathrm{ml}+\mathrm{IFN}-\gamma 10 \mathrm{U} / \mathrm{ml}$ at $37^{\circ} \mathrm{C}$ for up to $16 \mathrm{~h}$. The results are the means \pm S.E. of two independent experiments comprising duplicate assays. The symbols correspond to: control cells (treated with LPS +IFN- $\gamma$ ) (-४-), $3 \mu \mathrm{M} 1(-\bullet-), 3 \mu \mathrm{M} 4(-\bigcirc-)$, and $3 \mu \mathrm{m} 6$ $(-\triangle-) . * p<0.01 v s$. the corresponding controls (cells treated with LPS $100 \mathrm{ng} / \mathrm{ml}+$ IFN- $\gamma 10 \mathrm{U} / \mathrm{ml})$.

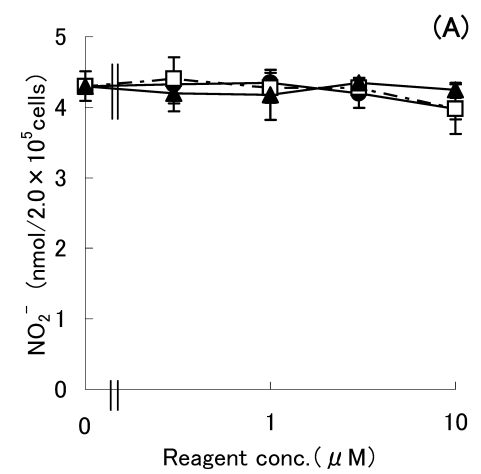

under these conditions. Bis(naphtho- $\gamma$-pyrone) derivatives showed no effects on NO production by activated macrophages, even at high concentrations $(10 \mu \mathrm{M})$. These results indicate that bis(naphtho- $\gamma$-pyrone) derivatives did not affect iNOS activity.

Inhibitory Effects on iNOS Protein Induction We next investigated whether bis(naphtho- $\gamma$-pyrone) derivatives affected induction of iNOS protein. Compound $1\left(\mathrm{IC}_{50} 0.8 \mu \mathrm{M}\right)$, $4\left(\mathrm{IC}_{50} 0.2 \mu \mathrm{M}\right.$ ), and 6 (inhibition at $3 \mu \mathrm{M} 48 \%$ ) markedly reduced the amount of iNOS protein (Fig. 5). However, 2, 3, and $\mathbf{5}$ had little or no effect on iNOS production. This trend was similar to that of the inhibitory effects on NO production over $16 \mathrm{~h}$. Therefore these inhibitory effects of bis(naphtho$\gamma$-pyrone) derivatives on NO production by macrophages are attributable to the inhibition of iNOS induction.

Inhibitory Effects on iNOS mRNA Expression We used RT-PCR analysis to determine whether 1, 4 and $\mathbf{6}$, which showed significant effects on iNOS protein induction, also inhibited iNOS mRNA expression in RAW 264.7 cells treated with LPS and IFN- $\gamma$. The quantity of iNOS mRNA and $\beta$-actin mRNA, a housekeeping gene, was estimated from the fluorescence intensity of the bands corresponding to iNOS mRNA (456 bp) and $\beta$-actin mRNA (540bp) in agarose gels. We determined the degree of inhibition using the iNOS/ $\beta$-actin ratio as an adjustment for minor differences in RT efficiency among the samples. Treatment with LPS and IFN- $\gamma$ for $6 \mathrm{~h}$ increased the level of iNOS mRNA expression (Fig. 6). The induced mRNA level decreased with increasing concentrations of the active compounds. At $3 \mu \mathrm{M}$, compounds $\mathbf{1}$ and $\mathbf{4}$ almost totally suppressed mRNA expression, and a low level inhibition of iNOS mRNA was seen at concentrations as low as $0.3 \mu \mathrm{M}$. The active compounds affected inducible iNOS mRNA expression, but did not affect constitutive gene expression such as that of $\beta$-actin.

At the gene level, the promoter of the mouse gene encoding iNOS contains consensus sequences that bind several transcription factors including the nuclear factor $\kappa \mathrm{B}$ and IFN regulatory factor. ${ }^{21,22)}$ Inhibition of iNOS induction by bis(naphtho- $\gamma$-pyrone) derivatives therefore may be mediated through the suppression of these transcription-activating factors, thereby inhibiting iNOS transcription. Bis(naphtho- $\gamma$ pyrone) derivatives, such as $\mathbf{1}$ and $\mathbf{4}$, are reported to exhibit antibacterial activity ${ }^{10)}$ and antitumor activity. ${ }^{11-13)}$ Therefore we speculate that bis(naphtho- $\gamma$-pyrone) derivatives may

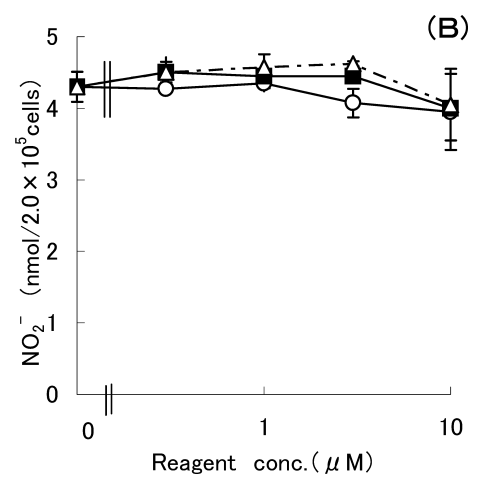

Fig. 4. Concentration Dependence of the Inhibitory Effects of the Bis(naphtho- $\gamma$-pyrone) Derivatives on iNOS Activity in Preactivated Macrophages

Cells were pretreated with LPS $100 \mathrm{ng} / \mathrm{ml}+\mathrm{IFN}-\gamma 10 \mathrm{U} / \mathrm{ml}$ at $37^{\circ} \mathrm{C}$ for $16 \mathrm{~h}$ and suspended in Hank's balanced salt solution (HBSS) $(+)$. Subsequently, cells were incubated with the compounds, and after incubation for $5 \mathrm{~min}$, carboxy-PTIO $100 \mu \mathrm{M}$ and L-arginine $1 \mu \mathrm{m}$ were added to the cell culture, followed by incubation for $60 \mathrm{~min}$. The symbols correspond to: (A) 1 (--), $2(-\square-)$, and $3\left(-\Lambda_{-}\right)$, and (B) $4\left(-\bigcirc_{-}\right), 5(-\square-)$, and $6(-\triangle-)$. The results are presented as the means \pm S.E. of two different experiments involving duplicate assays. 

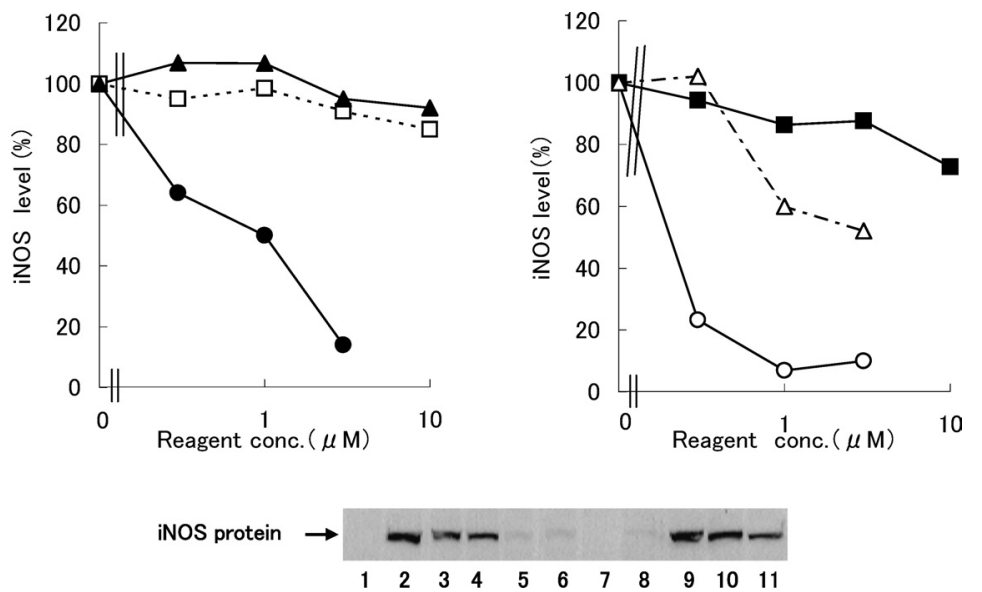

Fig. 5. Inhibition of iNOS Induction by the Bis(naphtho- $\gamma$-pyrone) Derivatives

Cells were treated with various concentrations of the compounds in the presence of LPS $100 \mathrm{ng} / \mathrm{ml}+\mathrm{IFN}-\gamma 10 \mathrm{U} / \mathrm{ml}$ for $16 \mathrm{~h}$. Cell lysates were then prepared and assayed as described in the text. The amounts of iNOS protein were calculated from the radioactivity of the bands corresponding to iNOS protein. We used an iNOS standard in the immunoblot analysis to normalize the iNOS amounts between different gels. The results are expressed relative to the amount of iNOS in $60 \mu \mathrm{g}$ of the control cells (100\%: treated with

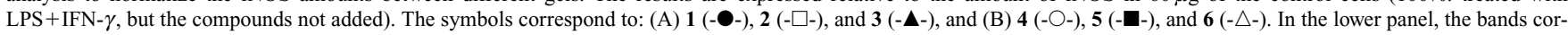
responding to the $130-\mathrm{kDa}$ iNOS protein are indicated. The numbers correspond to: 1 . control (absence of LPS or IFN- $\gamma$ ), 2 . control (presence of LPS + IFN- $\gamma$ ), 3 . $10.3 \mu \mathrm{M}, 4$. 1 $1 \mu \mathrm{M}, 5.13 \mu \mathrm{M}, 6.40 .3 \mu \mathrm{M}, 7.41 \mu \mathrm{M}, 8.43 \mu \mathrm{M}, 9.60 .3 \mu \mathrm{M}, 10.61 \mu \mathrm{M}, 11.63 \mu \mathrm{M}$.
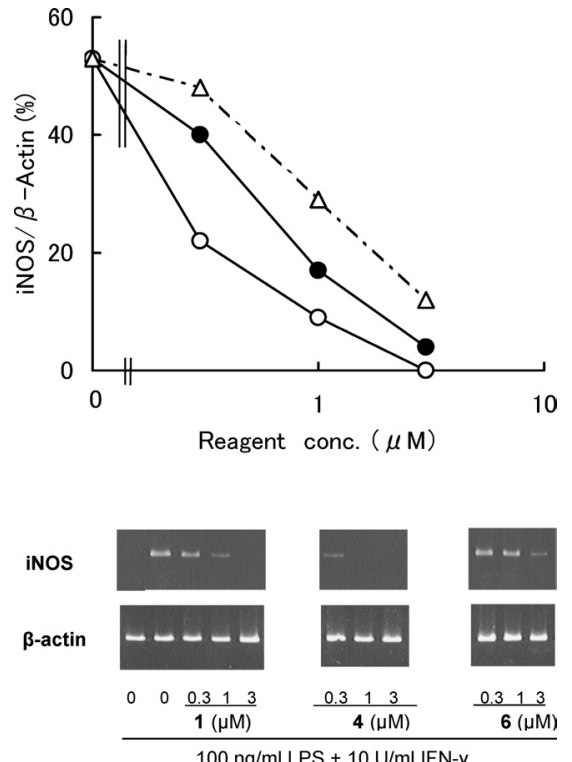

Fig. 6. Effects of the Bis(naphtho- $\gamma$-pyrone) Derivatives on iNOS mRNA Expression

Cells were treated with various concentrations of the derivatives in the presence of LPS $100 \mathrm{ng} / \mathrm{ml}+\mathrm{IFN}-\gamma 10 \mathrm{U} / \mathrm{ml}$ for $6 \mathrm{~h}$, and the cells were subsequently prepared and assayed as described in the text. The symbols correspond to: 1 (-0-), 4 (-O-), and 6 $(-\triangle-)$. The lower panel shows the PCR products corresponding to the iNOS (456 bp) and $\beta$-actin (540 bp) bands. The amounts of iNOS mRNA are shown as \% values relative to $\beta$-actin. The results are for a typical example of repeated experiments

affect inducible gene expression other than iNOS mRNA expression. Studies to determine the physiologic and pathologic functions of bis(naphtho- $\gamma$-pyrone) derivatives are underway.

In this present paper, we clarified that these bis(naphtho- $\gamma$ pyrone) derivatives inhibited NO production in the course of macrophage activation. We suggest that bis(naphtho- $\gamma$-pyrone) derivatives might play a role in modulating the inflammatory response by inhibiting NO production. The present findings encourage further studies to clarify the signaling pathway for the inhibition of iNOS protein induction by bis(naphtho- $\gamma$-pyrone) derivatives.

\section{REFERENCES}

1) Part 12 in the series on the contents. Part 11: Wang L.-Y., Unehara T., Kitanaka S., Chem. Pharm. Bull., 53, 137-139 (2005).

2) Adams D. O., Hamilton T. A., Annu. Rev. Immunol., 2, 283-318 (1984).

3) Bonta I. L., Ben-Efraim S., J. Leukoc. Biol., 54, 613-626 (1993).

4) Farias-Eisner R., Sherman M. P., Aeberhard E., Chaudhuri G., Proc. Natl. Acad. Sci. U.S.A., 91, 9407-9411 (1994).

5) Wei X.-Q., Charles I. G., Smith A., Ure J., Feng G.-J., Huang F.-P., Xu D., Muller W., Moncada S., Liew F. Y., Nature (London), 375, 408 411 (1995).

6) MacMicking J. D., Nathan C., Hom G., Chartrain N., Fletcher D. S., Trumbauer M., Stevens K., Xie Q.-W., Sokol K., Hutchinson N., Chen H., Mudgett J. S., Cell, 81, 641-650 (1995).

7) Stuehr D. J., Marletta M. A., Proc. Natl. Acad. Sci. U.S.A., 82, 77387742 (1985).

8) Stuehr D. J., Marletta M. A., Cancer Res., 47, 5590-5594 (1987).

9) Nguyen T., Brunson D., Crespi C. L., Penman B. W., Wishnok J. S., Tannenbaum S. R., Proc. Natl. Acad. Sci. U.S.A., 89, 3030-3034 (1992).

10) Matsumoto M., Minato H., Mitsugi T., Katagiri K., J. Antibiot., 28, 602-604 (1975).

11) Koyama K., Ominato K., Natori S., Tashiro T., Tsuruo T., J. Pharmacobio-Dyn., 11, 630 - 635 (1988).

12) Koyama K., Natori S., Itaka Y., Chem. Pharm. Bull., 35, 4049-4055 (1987).

13) Sekita S., Yoshihira K., Natori S., Udagawa S., Muroi T., Sugiyama Y., Kurata H., Umeda M., Can. J. Microbiol., 27, 766-772 (1981).

14) Koyama K., Natori S., Chem. Pharm. Bull., 35, 578-584 (1987).

15) Amano F., Noda T., FEBS Lett., 368, 425-428 (1995).

16) Ishii R., Horie M., Saito K., Arisawa M., Kitanaka S., Biochim. Biophys. Acta, 1568, 74-82 (2001).

17) Kanematsu M., Takagi K., Masuda N., Suketa Y., Biol. Pharm. Bull., 19, 949-951 (1996).

18) Ignarro L. J., Buga G. M., Wood K. S., Byrns R. E., Chaudhuri G., Proc. Natl. Acad. Sci. U.S.A., 84, $9265-9269$ (1987).

19) Bradford M. M., Anal. Biochem., 72, 248-254 (1976).

20) Akaike T., Yoshida M., Miyamoto Y., Sato K., Kohno M., Sasamoto K., Miyazaki K., Ueda S., Maeda H., Biochemistry, 32, 827-832 (1993).

21) Xie Q.-W., Kashiwabara Y., Nathan C., J. Biol. Chem., 269, 47054708 (1994).

22) Kamijo R., Harada H., Matsuyama T., Bosland M., Gerecitano J., Shapiro D., Le J., Koh S. I., Kimura T., Green S. J., Mak T. W., Taniguchi T., Vilček J., Science, 263, 1612-1615 (1994). 